\title{
Japan's International Education during COVID-19 Pandemic: Show Impact or Face Swift Death
}

\author{
Faramarz Samifanni ${ }^{1}$ \\ ${ }^{1}$ Fukuoka International University of Health and Welfare \\ Fukuoka, Japan \\ Email: fredsami [AT] takagigakuen.ac.jp
}

\begin{abstract}
The Japanese populace are dealing firmly with the Corona pandemic and effectively controlling it through the blockage of national and international travel; and effective advertisement of avoiding public places which are owned by both the government and private sector. There is no doubt that Corona has caused fears of practically everything tied to the human relationship including family ties and interactions of any close encounters, in terms of education, the greatest sector suffering are the private international education institutes since they heavily rely on student enrolments both within Japan for potential students and those schools who rely on foreign students studying in their institutions. Those depending heavily on foreign students would not be able to recruit from abroad and in turn, would be devastated by the lack of income. Also, there are some colleges and international universities that have study or work or short travel abroad programs that they cannot carry out for an uncertain period of time due to this pandemic which has choked the economy of many of these organizations including the companies and institutions connected to them. This paper analyses the current situation in the Japanese education system and look for possible solutions to the problem of Internationalization without international travel.
\end{abstract}

Keywords - COVID-19, internationalization, private education, student welfare

\section{INTRODUCTION}

Originating from the Southern province of China, coronavirus disease (COVID-19) pandemic has taken thousands of lives throughout the globe. As cases escalate every day caused by this upper-respiratory disease, people are absorbed by stress and uncertainties of where is the end. however, there is feeling by the researcher that intelligent and swift actions started by each individual such as looking positive and happy any movement to internationalize, can help in envisioning the future course.

The first three already existed and was doing a very rapid job of bringing private schools to their knees and bankruptcy. However, Corona has added a greater challenge that could quickly bring down the private schools to the verge of bankruptcy; especially those with the name International attached. Unless they have new solutions and move faster than the traditional methods of taking their sweet time and planning slowly.

With the "6-3-3-4 education system" in Japan, school-aged children must study six school years in grade school then another three long years in junior high school. The students than usually study three years more in high school before they can enter university and study there for four years ${ }^{[1]}$.

The results in the 2018 "Programme for International Student Assessment" (PISA) showed that Japanese 15-year-old high school students performed well in science and math. Among the 79 participating regions and countries, Japan ranked sixth in mathematical literacy with an average of 527. This was a step down from the country's fifth place in 2015 PISA with a 532 average. In scientific literacy, Japanese students gained 529 securing the fifth place which is three ranks lower from the previous assessment. Unfortunately, Japan's reading score only reached 504. Despite being above the "Organisation for Economic Co-operation and Development" (OECD) average of 487, Japan's current average abruptly declined from 516 in the 2015 assessment ${ }^{[2]}$.

The same results were reflected in the current "Times Higher Education World University Rankings" confirmed that Japan's leading school; the University of Tokyo is ranked 36th while the country's "second-best" Kyoto University lands 74th rank. Among the top 100 universities worldwide, only these two Japanese universities qualified. By country ranking, 
Japanese universities only ranked 10th in the world which means that it has the same quality with Chinese and South Korean Universities ${ }^{[1]}$.

Decades ago, Japanese schools were among the leaders in the world university ranking. But these assessments reveal that there is something wrong with the Japanese education system. While the country is leading the world in technology and innovation, school leaders are neglecting a crucial aspect: internationalization of education.

With these premises, this article aims to address the following question:

RQ1: What is internationalization in Japanese universities?

RQ2: How to embrace internationalization in the face of COVID-19 travel restrictions?

\section{MATERIALS/ METHODS}

This study utilized the Data Mining method and desktop study about the relevant data on COVID-19 pandemic and pertinent information about the Japanese education in relation to the present article.

\section{COMPETITIVENESS IN THE INTERNATIONAL ARENA}

After World War II, the Americans brought a new system of tertiary education in Japan. This made key restructurings to Japan's colleges and universities. Commencing in the $1990 \mathrm{~s}$, the storm of transformation that sustained to blow within the arena of higher education [3].

Until lately, it was observed that higher education required or warranted support from public funding, where the national and local governments are accountable to deliver. This is observable in the case of Europe and America where $80 \%$ of the students are enrolled in public schools. However, the Japanese private school sector accounts for almost $80 \%$ of the student body; government funding is tremendously minimal [3]. To continue their operations, these self-supporting private institutions rely on their "tuition fees" which sums to $70 \%$ of the universities" entire income [4]. At present, private universities receive about $12 \%$ of expenditure, "a figure which has changed little in the past decade" [5].

With the COVID-19 pandemic, Japan's privately owned colleges and universities are mainly struggling for funds, students, and faculty. In 2016, more than $90 \%$ of education expenditure was disbursed to pre-tertiary education, parallel to the average of OECD countries. But, a frugal $31 \%$ of tertiary instruction expenses were subsidized by the government, having the least budget amongst OECD nations. While 53\% of the students' school fee was obtained from their families and another $17 \%$ from some private organizations, the unaffordable school fees remain a worry to study in a Japanese university. This made many students facing large education loans averaging to USD 28300 . Japanese aim for quality education is seen through their strong drive to reach tertiary education. In 2018, more than 50\%of 25 to 64-year-olds had achieved college and university education. This figure was " $13 \%$ higher than the OECD average." While the majority of the student-aged Japanese can reach university, it is quite observable that the population is homogenous. This shows that amongst the OECD countries, Japanese universities have a comparatively small percentage of "adult and international students" [6].

It seems that Japan has a more stringent system of admission. Commonly, applicants are evaluated based on their "performance in a standardized national test and/or examination administered by each institution." These colleges or universities also consider the applicants' performance at "upper secondary schools" along with interviews and other means to measure their qualifications for university or college admission. With this system and factors like privatized development in college and university education and "youth population decline", about $40 \%$ of private tertiary education institutions failed to reach their "government-allocated enrolment quotas" last 2018 [7].

Japanese universities must consider diversity in entrance exams for future student- applicants [1]. There is a decrease in high school graduates in Japan in recent years. More than half of these graduates shall not pursue university due to many reasons. The only option of private and even public universities is to absorb international students who could barely afford to enroll. These put the universities more pressure to reach and sustain their student enrolments in the global arena of internationalization. 


\section{HINDRANCES INTENSIFIED BY COVID-19}

The following factors putting the private schools' operation at a disadvantage is aggravated by the COVID-19 pandemic are discussed below.

\subsection{Decreasing Population}

It is not new for Japan to report a decreasing population. However, in 2018, CNN reported that Japan marked a "new record" for the least birth since 1899. The number decreased by 25,000 since 2017. For three years straight, Japan has had fewer than a million birth since the updated registry initially started. Concurrently, Japanese deaths have reached 1.369 million. These factors make the peak of a natural population waning in Japan's history ${ }^{[8]}$.

Aside from the low birth rate and high mortality rate, the fast aging of the Japanese populace is a main public policy concern. The main issue on the decreased working population is many would soon retire while lesser offspring are being born to substitute the labor force. A declining labor force reduces economic growth which entails the reduction of savings and levels of investments ${ }^{[9]}$. The Japan Times stated that Japan's birth and death data display that the "population collapse" is fastmoving. Around 127 million people are living in Japan. This figure could bead below the 100 million cuts by the year 2050 (Fig.1) as projected by the "National Institute of Population and Social Security Research" (NPR) ${ }^{[10]}$.

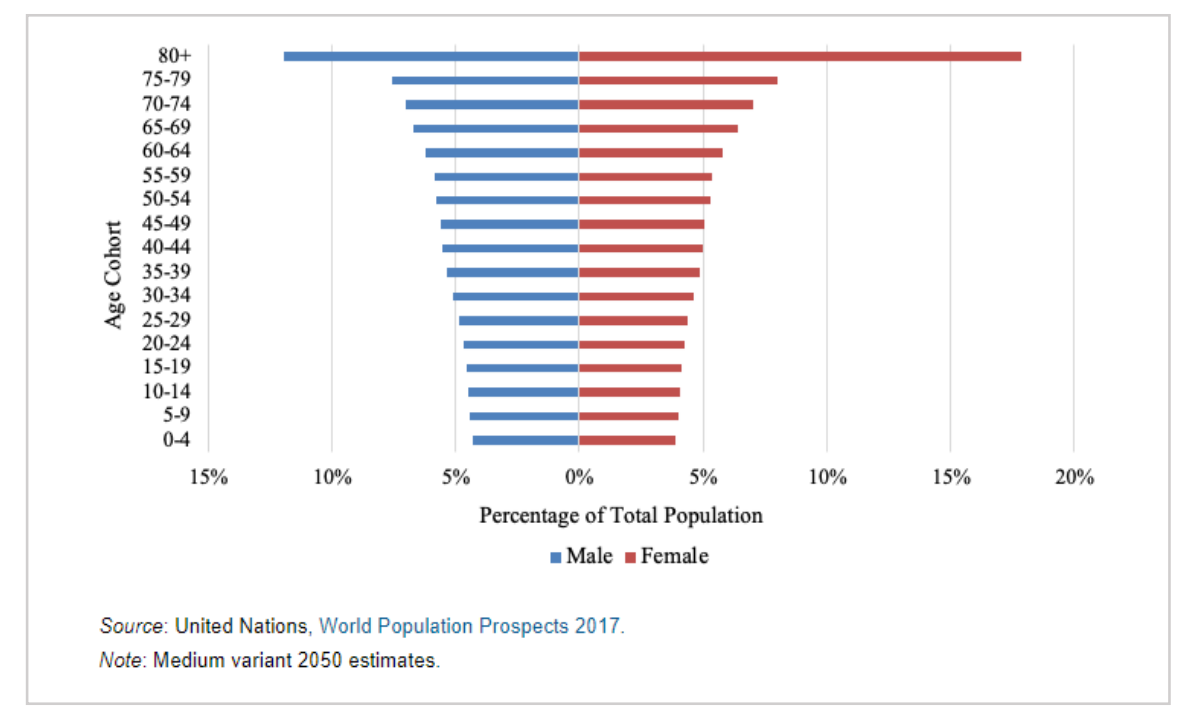

Figure 1. Japan's Projected Population in 2050

In ten years, the Herculean struggle to solve the Japanese population aging will be daunting ${ }^{[11]}$. Moreover, the rapid and widespread of the COVID-19 pandemic is a huge concern and aggravating factor on the decline of the Japanese population. Although the country has reported low cases of infection, the disease is killing the weakest of the population. Most reported cases are those who belong to the "rearing age." If the trend goes on, there is a possibility that the projected figures for 2050 will be lower because of COVID-19.

As of May 7, the cases of COVID-19 have been severely affecting the older population (Figure 2). As illustrated, most cases of "severely ill patients" belong to the 60 to 69 years-old age brackets, which sums to 89 cases. Moreover, patients who belong to the 80 years and older were reported to have the highest sum of deaths with 228 cases.

Due to the rapid decline of the 18-year-old Japanese population, companies tend to believe that mergers between and among private universities are crucial to their existence. However, this could be an unlikely move. Within a global viewpoint, the demand for universities is increasing; in fact, the international population is growing and the middle class is escalating, this is observable in developing countries with rising economies. From a global perspective, higher education is a growing industry ${ }^{[1]}$. 


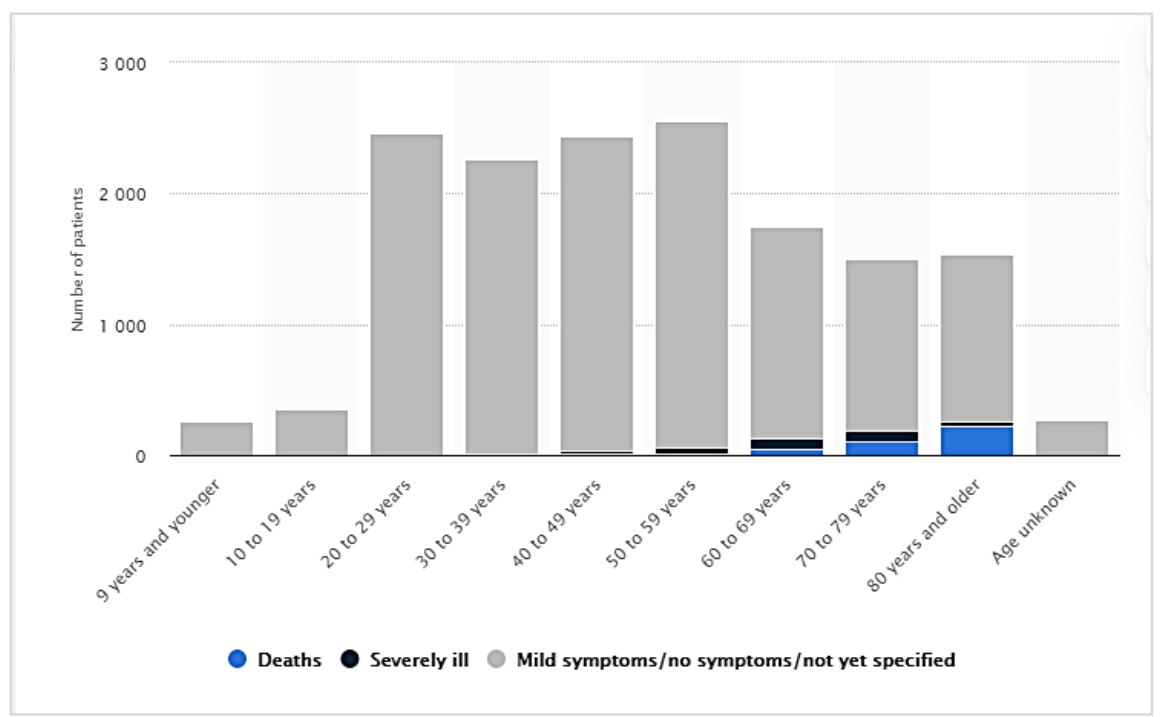

Figure 2. Japan's distribution of coronavirus disease

Source: Statistica.com ${ }^{[12]}$

\subsection{Weakened Economy}

Success to the Japanese workers is defined by long office hours, plenty of overtime, and after-work drinking with clients and superiors. This "workaholic culture" is starting to vary due to the COVID-19 pandemic. It is high time and companies have realized that their employees can do work from their homes. Panasonic and Unicharm are two of the leading companies which introduced the "work from home" scheme that made headlines with the onset of the deadly pandemic in Japan. The massive spread of COVID-19 caused school closures and made people distant from each other. Gatherings were canceled and sports events, such as the Tokyo Olympics 2020, were postponed. The government has advised the general public to avoid drinking and partying ${ }^{[13]}$.

Based on Nihon Keizai Shimbun's survey on approximately 140 chief companies in Japan, around $50 \%$ partly adopted the "teleworking scheme." The pandemic is extremely detrimental to the economy of Japan ${ }^{[13]}$. In 2019, Japan welcomed 31.9 million foreign visitors making the country a "tourism mecca." The figure was considered highest after seven successive years of progress. Before the pandemic hit Japan, Prime Minister Shinzo Abe said that the country expected to attract 40 million foreign travelers in this year. However, the pandemic had caused travel bans to bring a halt to Japan's tourism sector by a $99.9 \%$ drop of travelers last April; the season for sakura sightseeing. About 7\% of Japan's Gross Domestic Product comes from its travel and tourism sector. In this era of economic decline and difficult times caused by COVID-19, everyone is eyeing the Japanese administration's further measures to avoid failure and permanent "closures of family businesses" not to mention the private universities ${ }^{[14]}$.

It is difficult for private universities and smaller companies to be financially secured than larger companies, and this sector suffers the hardest during recessions as local demand falls. With Japan's declining population ages, numerous family and privately-owned businesses with senior owners besiege to find descendants to look after the business ${ }^{[15]}$. As the NLI Research Institute predicted, the enactment of the "COVID-19 state of emergency", made 700,000 workers jobless, with almost 750 thousand unpaid workers and financially suffering families. Despite the low number of infected cases in Japan; roughly 16,000 with an estimated 800 reported deaths. However, experts say that there are more cases and fatalities as tests are only conducted to patients with severe symptoms. Nevertheless, above $35 \%$ of homes are experiencing drops in revenue, while over $50 \%$ are "expecting income cuts" while another $47 \%$ of the workforce are afraid of losing their jobs $[16]$.

There is no difference between the lost life due to COVID-19 is from that of a great recession. Death is considered a tragedy regardless of origin. What is more, considered tragic is people avoiding one another, starving families and bankruptcy, and closure of businesses in an attempt to control the dreaded disease but less fatal than tuberculosis ${ }^{[16]}$. For those ultraconservative private school owners and leaders of schools who are used to slow changes, Corona came fast and hit hard; change must be decisive and fast to save the institution from a rapid decline in student enrolment and swift bankruptcy.

\subsection{Deregulation of Universities}

Later in the late 19th century, Japan decided to centralize its organizations, which included education, trying to be at par with the industrialized countries of the West. Lately, deregulation and decentralization were in progress in all facets of the instruction. Simultaneously, numerous assessment schemes were presented to guarantee the high quality of education. Despite these new procedures being practiced, the effect of those changes remains unclear ${ }^{[17]}$. 
In 1983, the Liberal Democratic Party administration began on changing government policy which was coined "regulation reform" and "structural reforms." This program sustained the past 2001 leading to a momentous influence on "university reforms." The chief policy reform was the Japanese administration's verdict to "relax" guidelines regarding tertiary education institutions. This "liberalization" became serious during the early ' 90 s with the extensive revisions done with "Standards for Establishment of Universities (Daigaku secchi kijun)," or "the organization of universities" which laid down the rudimentary circumstances of tertiary education. These transformations provided more autonomy to universities allowing them to decide and organize curricula, tuition fees, and freeing them from strict guidelines ${ }^{[18]}$. This paved to absolute innovation or renaming of departments and programs. With the relaxed the guidelines for official university recognition, universities swiftly increased in numbers; from 507 official schools in 1990 increasing to 649 in 2000 , and 782 in 2013 (Figure 3).

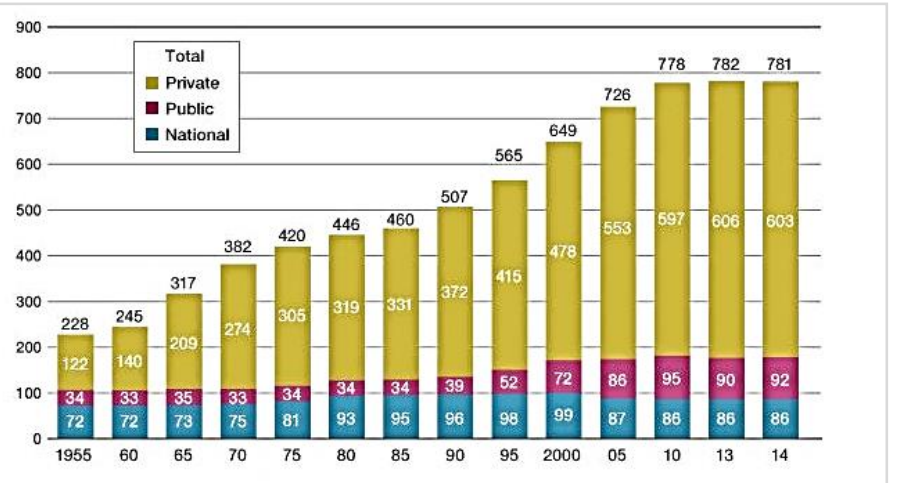

Figure 3. Japanese Universities from 1995-2014 source: MEXT, nippon.com ${ }^{[18]}$

The figure shows that private universities comprise twice the number of universities in the country. Despite the freedom given to these universities, only the national universities are funded by the government. Private universities are currently facing pressure to further advance and involve in a fiercer struggle for survival ${ }^{[3]}$.

At the beginning of 1990 , there was an observed $40 \%$ decrease in the "18-year-olds" population, this is why the plethora of universities are besieged with few students. In the past decades, it was typical to see more applicants than openings in universities where applicants need to undergo the trial of the "exam war". This makes students do years of exhaustive study in preparation for difficult entrance exams. Now, it's the universities running after their prospective students with varied marketing strategies.

Numerous private universities opted to have open campuses, where tours and school information are given to prospective students. They also offered alternate admission paths like the "AO (admission office) entrance exams" where discussions and students' essays on their motives for selecting the school are given consideration instead of their academic attainments. Currently, university admission is a matter of choice and no longer a challenge. The portals to university are widely open. However, the shrinking enrollees further ahead cause the university managers to face the challenge of decreased income from entrance exam fees and tuition. In response to this issue, the education ministry made an initiative and declared qualified universities for its "Top Global University Project." According to the ministry, this scheme would advance the "international competitiveness of Japanese higher education" through "prioritized support to top universities" that involve in world-class teaching and study. It also includes universities that confidently encourage "internationalization" and improvement ${ }^{[18]}$.

\subsection{Corona virus and the Private Universities}

The COVID-19 pandemic had caused many school closures and the economic impact disturbed the education of nearly 290.5 million public and private students globally reported by the United Nations Educational, Scientific, and Cultural Organization (UNESCO) ${ }^{[19]}$. There are promoters of starting the Japanese school year in April as cherry blossoms flower. Despite the closures brought by the pandemic, advocates see this as an opportunity for internationalizing education. The anticipated change to a September class opening, similar to Western countries, greatly affects company employment because the majority of companies do mass hiring in April; where new graduates face the real world and the start of the fiscal year ${ }^{[19]}$.

Despite the positive foresight in the class openings, a recent survey found that one out of 13 university Japanese students considers quitting school because the COVID-19 pandemic made families lost their livelihood or monetary assistance. The said survey, led by "a student group advocating tuition-free higher education named Free," presented that around $60 \%$ experienced income loss; another $40 \%$ stated their parents and relatives were also coping financial problems. The survey accounted for around 500 tertiary students which revealed that " $37.4 \%$ were earning less from their part-time 
jobs, while $23.0 \%$ are not earning at all." Regarding people financially assisting them like their parents, $36.4 \%$ stated their source of revenue had decreased, and $3.3 \%$ experienced a total loss of income ${ }^{[20]}$.

In Japan, numerous students had chosen to leave university studies due to economic difficulties. The COVID-19 emergency and lockdown cost part-time jobs and financial problems of university students and their families ${ }^{[21]}$. Even though some universities provide aid to students; Prime Minister Shinzo Abe assured a broader assistance package for these students. Nevertheless, the education sector perceives opportunities from COVID-19 for extensive improvements of the higher education system which includes steps to online education and variations in Japanese academic school year aligning to the West ${ }^{[21]}$. This would bring a great impact on enrollment.

\section{EMBRACING INTERNATIONALIZATION}

When Prime Minister Shinzo Abe proclaimed a national school shut down in late February, the instructors needed to completely "re-imagine" their functions. A huge shockwave was to suddenly shift to digital modes of instruction; a massive backlog to the traditional Japanese classroom. In a survey conducted by the OECD in 2018, Japan got the least fraction in its teaching force who had the essential skills in multimedia during instruction ${ }^{[22]}$. With this at hand, authorities see that the present educational challenges could serve as a window for the Japanese education system to level up in using educational technology. It is high time for Japan to adopt the blended learning scheme and provide education through technology ${ }^{[23]}$.

Aside from blended learning, the post-corona era would mean the resumption of face-to-face lessons and private universities still coping with the massive decline in revenue. The challenge towards internationalization may seem Herculean but there are ways to realize this arduous task. Internationalization experience can be provided to the students through an international lounge using English only as a medium of communication. It is a setting with rules such as anyone entering the room use only English as the spoken tool for communication or simply an "English only zone or room" for everyone in the university. The lounge could serve as an information hub about other countries language-study programs and culture. The lounge could be a relaxing place and welcoming those who would like to have a conversation in English or just enjoy English reading and multi-media materials. The room could also provide magazines or comic books in English including audio-visual relaxing and fun things that students could be interested in. This place could also be a liaison between the student organization and the students' voice to the administration on the international needs and vice versa. It could organize lectures and talks and even celebrations and parties relating to international events. It could encourage fundraisers and charities relating to both national and international issues.

As a center of international knowledge and cultural exchange, an English international lounge could help to open the doors to international communication with English speaking and international instructors being there for assisting the students as well as promoting the core ideas of the education institution. Moreover, this move can attract more students because they do not need international travel since the school is providing an international experience in the lounge; the fear of international travel is no more a concern. Lastly, the lounge could be a bridge for stakeholder partnerships to the city and the prefecture which have International Associations which we could hold talks on our campus. Utilizing the present human resources of the university in implementing an international objective is practical and does not require travel abroad. Having an English international lounge is like bringing to the world to the university at a minimum cost.

\section{CONCLUSION}

Terrorism being the horror of the end of last centuries' main fear, the researcher believes that this century has COVID19 as the Mother of all terrors and horrors of the beginning of this century since it has no limits or clear boundaries. So far, the pandemic has not only murdered hundreds of thousands and has not stopped, but also put a halt to internationalism and devastated every aspect of human socio-cultural and economic life without any foreseeable end. Aside from the decrease in population, COVID-19 has had a great impact on those interested in enrolling international institutions to look for what would be international about the school they might be joining in. COVID-19 has stopped all International travels and scared many Japanese and foreign students to travel abroad. So, International Private Institutions have either stopped their study abroad programs and also stopped recruiting students from abroad. In many cases, students were forced to withdraw and in other cases even if not forced by the government immigration regulations, parents hesitated to allow their kids to take the study abroad short- or long-term programs.

However, like any evil movement that should be dealt with, we need not submit to its demands and take advanced actions that would show our innovativeness. Through internal resources such as connecting with international organizations and local foreigners to create and enhance internationalism and save the face of international educational institutes. One way of creating impact is to show attractiveness despite the lockdowns and blockages of internationalism such as creating an international lounge or bombarding the walls with other cultures and other nations' photos and English language expressions. This way, visitors can see how the International institute is trying to keep its integrity despite the consequences of COVID-19. Meaning, an international education institute without any impact or emphasis on internationalism would 
contradict its name. Either way, International colleges and universities to survive the COVID-19 pandemic must take measures to sustain their international integrity and reputation through diligent and essential movements and have an impact. Japanese institutes have a very slow and conservative character when it comes to revolutionary changes to through their administrative systems where two-thirds of their time is designated in planning and one third is in production and often this works to perfect products. However, in the case of COVID-19, it came suddenly and was swift in showing its impact through massive annihilation; and so, the life of international education institutes strongly depends on their swift positive actions with great impact on internationalism or face the consequences will be a very fast and quick death.

\section{ACKNOWLEDGEMENT}

My deepest gratitude the Creator of all Good Thoughts, Good Words and Good Deeds as well as to the leaders of my university, Director/Owner Doctor Kunitaka Takagi, President Doctor Tsutomu Imaizumi, Vice President Doctor Hitoshi Maruyama and the heads of OT, PT and ORT departments for their support and positivity in allowing me to improve the students' language communication skills.

\section{REFERENCES}

[1] H. Deguchi, "The direction of education in Japan," The Japan Times, 30 September 2018.

[2] UNESCO, "Japan," 2018. [Online]. Available: http://uis.unesco.org/en/country/jp.

[3] A. Ikuo, "Globalization and Higher Education Reforms in Japan: The Obstacles to Greater International Competitiveness," 11 March 2014. [Online]. Available: https://www.nippon.com/en/in-depth/a02801/.

[4] M. Baba and T. Tanaka, "Government Funding Versus Private Funding in Japanese Universities," Quality in Higher Education, vol. 3, no. 3, pp. 263-276, 1997.

[5] F. Maruyama, "Financing Universities in Japan," 2002. [Online]. Available: https://www.niad.ac.jp/media/001/201802/pdf/nk002002.pdf.

[6] OECD, "Education at a Glance 2019," 2019. [Online]. Available: https://www.oecd.org/education/education-at-aglance/EAG2019_CN_JPN.pdf.

[7] The Promotion and Mutual Aid Corporation for Private Schools of Japan, "Heisei 30 nendo shiritudaigaku tankidaigaku tou nyugakushigan doukou [Enrolment Trends in Private Tertiary Education Institutions 2018]," 2018. [Online]. Available: https://www.shigaku.go.jp/files/shigandoukouH30.pdf .

[8] T. Pacis, "Japan's population is shrinking faster than ever before," 12 June 2019. [Online]. Available: https://dailyhive.com/mapped/japans-population-shrinking-faster-2019.

[9] M. Morikawa, "Hidden inflation: Japan's labour shortage and the erosion of the quality of services," 31 March 2018. [Online].

[10] S. Ingber, "Japan's Population Is In Rapid Decline," npr.org, 21 December 2018.

[11] D. Bloom, P. Kirby, J. Sevilla and A. Stawasz, "Japan's age wave: Challenges and solutions," 3 December 2018. [Online]. Available: https://voxeu.org/article/japan-s-age-wave-challenges-and-solutions.

[12] Statistica.com, " Patients profile of coronavirus disease (COVID-19) cases in Japan as of May 7, 2020, by age group and state of health," June 2020. [Online]. Available: https://www.statista.com/statistics/1107703/japanpatients-detail-coronavirus-covid-19-cases-by-age-and-state-of-health/.

[13] R. Takeshita, "How can we prepare for the post-coronavirus era? A view from Japan," 7 April 2020. [Online]. Available: https://www.weforum.org/agenda/2020/04/japan-covid-19-situation-and-coronavirus-impact/.

[14] T. Siripala, "Japan's Campaign to Revive Virus-Hit Tourism Sector Postponed Amid Cost Controversy," 16 June 2020.

[15] A. Martin, "Japan's economic backbone creaks under the weight of COVID-19," The Japan Times, 25 April 2020.

[16] L. Miura, "It's time to face the real risks posed by COVID-19," The Japan Times, 24 May 2020.

[17] H. Muta, "Trends and issues in deregulation and decentralization of educational administration in japan," in Educational Decentralization. EDUCATION IN THE ASIA-PACIFIC REGION: ISSUES, CONCERNS AND PROSPECTS, vol. 8, Dordrecht, Springer, 2006, pp. 97-113.

[18] nippon.com, "Universities Struggle to Cope with Shrinking Population and Globalization," 16 March 2015. [Online]. Available: https://www.nippon.com/en/features/h00095/universities-struggle-to-cope-with-shrinkingpopulation-and-globalization.html.

[19] K. McCarthy, "The global impact of coronavirus on education," abc news, 7 March 2020. 
[20] The Japan Times, "One in 13 college students in Japan considering quitting due to COVID-19, survey finds," The Japan Times, 26 April 2020.

[21] S. Kakuchi, "COVID-19 hits student finances, amid calls for wider reforms," universityworldnews.com, 8 May 2020.

[22] J. O'Donoghue, "In era of COVID-19, a shift to digital forms of teaching in Japan," The Japan Times, 21 April 2020.

[23] L. G. Kittaka, "Coronavirus crisis offers chance to update Japanese schools," Japan Times, 20 April 2020. 